\title{
PARADOX OF DIGNITY: NOTES ON EXISTENTIAL LUXURY AND POLITICS OF QUALITY
}

\author{
Žarko PUHOVSKI, PhD \\ Faculty of Philosophy, University of Zagreb \\ Email: zpuhovski@gmail.com
}

\begin{abstract}
Human dignity has been the foundational principle of choice of both international human rights law and domestic constitutional rights provisions since the end of the Second World War. However, in spite of widespread international consent on the importance of this principle, there is a significant degree of confusion regarding its true meaning. Much of this confusion steams from loose usage of the term and its inherent imprecision. This article analyses different meanings of the notion of dignity from semiotic, linguistic, historical, philosophical and social perspective. It takes into account its dual significance in modern times: first, it is the widespread claim that human dignity represents a foundational on which human rights are based on, and second that dignity has obviously power to serve as indirect motivation for numerous and quite different protest movements, which claim to originate from the indisputably deep and often unspecified frustration. The key hypothesis is that the notion's imprecision is what enables its pervasive use in the public sphere and for different causes. In other words, this article aims at disclosing the paradox of dignity due to the fact it is a highly subjective concept, to a high degree a delicate constituent of (classical) understanding of a person, as well as an element of the (modern) concept of human rights. Furthermore, it is a robust component of the social upheavals across the globe.
\end{abstract}

Keywords: dignity, paradox, human rights, protest movements

\section{Introduction}

The essence of the fundamental dissatisfaction that engulfs the world today has been defined adequately in the words of the popular literary character Huckleberry Finn since long ago. Namely, trying to teach a runaway slave Jim about the meaning of Europe, he says that in Europe there are kingdoms, and on Jim's question what are kingdoms and kings, he replies that he does not need to know anything but only that kings are simple frauds (Twain, 1994).

Approximately, 125 years later a mass movement was born in Spain and in some moments it engulfed almost entire (developed) world: Indignados actually repeats the same pattern. It relies on the enormously popular booklet entitled Time for Outrage Indignez-vous! (Hessel, 2011). (This brochure has in quite a degree revived the original meaning of the infamous term 'pamphlet'; the term originates from a two hundreds years old amatory comic poem entitled Pamphilus 
seu de amore (Pamphilus, or About Love), in which the name of the main character comes from Пá $\mu \varphi\left(\lambda \circ c_{\text {, }}\right.$ loved by all).

The rebellion advocated by Hessel and his young followers is characterised precisely by rage based on the belief that all one needs to know about "those up on the top" (i.e. the elites, the establishment) is that they are simply - scoundrels. The key arguments about them being rascals is the very fact that they are on the "top" - otherwise, how would they get there if not because they are such rotter. Evidently, this starting premise is extremely imprecise, and even (socially, politically, and ideologically) disoriented. It is precisely why it is easily embraced as a motivational factor by very different protest movements, which often has become quite powerful. Their roots derive both real existential social despair and indirectly transferred and glorified despair. As in many other occasions in the past, quite a number of activists take initiative on behalf of the others, including the ones who are not aware of their desperate situation so therefore they, among other things, need to be made aware of their disadvantaged position.

Just a half a century prior to these events, on the peak of the student protests, on a public debate in Berlin (in September 1967), Herbert Marcuse (1978) paradigmatically formulated the key premise of such currents (despite the fact that it had already been emptied of any essential content): "If one wants to build a residential building on the place of a prison, then $\mathrm{s} /$ he needs to really destruct the prison, which prevents the construction of the other building... It is not necessary to have a precise plan of that residential building in order to start with the demolition of the prison - if there is will and strength for that ... Details could be agreed later on".

It is the very same motivational narrative at place now: it calls upon will (and hopes for strength). Nowadays it takes not harmonious adolescent version of the junior legend "Green Greta": "The people don't understand how angry the young people are because of the climate change are, they underestimate outraged children. They are angry and frustrated." (Hina, 3. 12. 2019.) Indeed, the dynamics of quite different movements originate from the indisputable deep, and often unspecified frustration. The attempt of the psychoanalytical literature in Croatian language to explain the frustration as deprivation is not very adequate because it de facto confuses the cause and the consequence of the motivational pattern. It looks as if there is no need for any further precisions of frustration; in the political understanding, any additional explication would de facto only impede 'our cause' since it may lead to narrowing the 'main front' of the movement.

\section{On Dignity}

The power of the indirect motivation that moves a mass of people relies precisely on the word's imprecision, which is in intimate connection with one of the fundamental elements of both individual and collective identity: i.e. dignity. Hurt/lost (or in a rather pathetic but motivationally more productive "stepped on" version of) dignity proves to be continuously explosive mix (of social, political, psychological elements), which easily produces outrage or rebellion. It is often turned towards everything, and sometimes against anything. Denial of dignity almost by default provokes revulsion, frustration, despair, and rage. 
The paradox of dignity as socially accepted value lies in the fact that it is simultaneously: a very subjective concept, to high degree a delicate constituent of (classical) understanding of a person, as well as an element of the (modern) concept of human rights. Furthermore, it is a robust component of the social upheavals.

Specificity of dignity as (a primarily moral) reservoir for initiation of social movements (but also of individual living strategies) lies exactly in its content vagueness that it introduces into communication. Any breach of equality or freedom is relatively easy to be detected, quite often even on empirical and quantitative level. Moreover, they have a clear equivalent on the opposite side: inequality and subjection. Counter-term to dignity does not exist in majority languages, at least not as a noun. $0 \mathrm{n}$ the other hand, however, there is a negative attribute: undignified.

A number of modern languages use the term that originates in Latin dignus, meaning worth, appreciated; the German term Würde is derived also from Wert, value. But, in many Slavic languages (such as Croatian, for instance) the origin of the word is more cynical if understood literally: dignified (dostojanstven/a) is the one who stands next to another (assumedly that other person is important, powerful, respected). The original Croatian meaning of the word 'dignity' thus does not take into consideration the essence that is very important in the view of numerous philosophical and religious interpretations: i.e. standing against all odds, or external factors. For such an implicit understanding Hobbes' dictum indeed rings true: „to consider the ones who give commands as dignified ... is nothing but an argument and symbol of power" $(1982$, p. 152). In other words, power simply spills over into a (social) respect, and also dignity as a power symbol.

Socially assumed dignity used to work also as a moral framework imposed from above: knight's virtues in the Middle Ages were associated exclusively with one's social affiliation (with very few exceptions), and later on they became a foundation of a wide concept of fairness. In its modern version this concept (regardless the fact it was distilled from rather cruel social contexts in which the original was born) is popular and acceptable. At first, it applies on the level of individual appreciation, but when applied on groups and collectives it creates serious difficulties (which is nowadays most visible in terms of its national/patriotic expressions). In short, it is possible to see it systematically spread on entire nations and their political self-understanding - up to the Prussian existential of Frederick the Great: "It is not necessary that I live, but I must do my duty".

Duty before life is the summary of a century-long exercising of dignity, which turns from a social privilege into (submissive, and also later - a citizen's) duty. Probably it was not a coincidence, although surely it was done with no awareness, such a post-feudal understanding of dignity has been expressed by former Croatian president Kolinda Grabar Kitarović in her farewell speech: "I have been defending and promoting the interests of the Christian people, the State and all citizens with dignity and responsibly ... above any other partial interests" (N1 Hrvatska, 15 February 2020). The notion of dignity that goes beyond interests is of premodern rather than of citizen quality because it assumes that interests (especially, personal ones) is impossible to represent with dignity. Thus dignity remains reserved for a sphere that is above all conflicts and 
contradictions, approximately on an assumed level of sovereign objectiveness; all the others are situated in a position to be treated as 'mere particularity'.

Duality of internal and external (social) expression of dignity manifests one more categorial paradox. Namely, through its various and different usages, the term 'spreads over' widely - from the stoic understanding (which implies that internal dignity of a person can be preserved even in circumstances of suffering and injustice all around) up to slavery and feudal systemic attachment of dignity with one's origin (class); later on there were more sophisticated models of socialization of dignity understood as privilege. The dual obstacle to reaching dignity for all and always is the key impetus for powerful - although not quite differentiated - dissatisfaction, and even despair. It manifests into either as isolated self-revived groups that occupy positions of institutionalized dignity, or in a way when powerful classes directly disable dignified life of the majority, using direct means for suppression.

On a level of everyday social differences the sad English proverb that reads "Beggars can't be choosers" illustrates the best the limitation of life in poverty (that no pastorals can change or cover), because the possibility of choice is one of the elements of societal dignity. Thus, in the long tradition, it is often understood as accompanying phenomenon of existential luxury, i.e. as life quality that unprivileged people are generally deprived of. This is why it is highly irresponsible to link dignity as such with extreme situations in which the options are necessarily limited or even non-existent (there cannot be a mention of any luxury). The national discourse in Croatia over the alleged 'dignity of Homeland War' ("dostojanstvu Domovinskog rata") is just a sad (and not very original) example of misuse of such a great (both traditional and modern) value. Dignity can be associated primarily with individuals (soldiers in this case, for instance), but not with a historic event as war certainly is, especially is the war has had a rather brutal form of indiscriminate warfare against civilians. War can be fought for the sake of sacred or great cause; it is even possible to behave (although in a limited number of occasions) in a dignified way, but the warfare can be dignified only in the eyes of those who simply despise human survival believing that it is not only necessary but even just to sacrifice thousands of human lives for the Cause.

In the Eastern tradition, i.e. the Buddhist one, dignity is - again inherently - in the human capacity for self-perfection. Western legacy is essentially determined by terminological apparatus of Giovanni Pico della Mirandola as continuation of Cicero (who associates dignitas with auctoritas even more intimately) as well as with the Christian understanding of dignity. By taking into account for the first time ever even Kabbala, on one hand Pico - quite typically for the traditionalistic approach - understand man as a being whose dignity arise from the premise that he is "synthesis of universe" (1994). On the other hand, however, even in the first contours of modern anthropology, man as microcosm in which the entire process of creation is repeatedly carried out, is able for the act of self-determination by one's own free decision, which then situates him in the adequate place in the world. Dignity consists of that potential for making free decision of oneself. This is far before Descartes, to whom Heidegger assigns this as a modern threshold, because in this original context it is a matter of self-situating the man as a moral subject. 


\section{Security}

Enlightenment focuses on the ideal of overrule of urges through the moral strength, which is externally expressed as dignity. However, the individual existence is still the focal point; its guarantee (as formulated paradigmatically by Kant) is in autonomy that is "human character's foundation of dignity" (2016, p. 436). Yet, no matter how moral considerations were constitutive for such an individualistic understanding, they were inevitably intertwined with the social contexts. For a long time they were an object of deliberation on the track of Kant's thoughts. Hence, Schiller (1969) elaborates the entire problem primarily in educational/enlightening manner: "Suppression of urges through the strength of moral power is indeed spiritual freedom, and dignity is just an expression of that phenomenon". However, a couplet led him later on directly to the very societal conditions that had been marginally mentioned in his lofty deliberations: " You just give him to eat, to dress, a roof over his head, and the dignity comes by itself" (1980). It does not take much to get from radically enlightened notion of dignity to its (originally silenced) societal context.

Summarizing Schiller's social radicalism, a few generations later, in his play "The Threepenny Opera" Brecht coined the famous materialist slogan that reads: "Food is the first thing, morals follows on". This is a paradigmatic determination of the already mentioned existential luxury in which one can start talking about dignity. In his theoretical deliberations, he advocates the standpoint that the term "honour" should be replaced by the term "human dignity", because honour is something external, while dignity is internal value. Brecht's understanding of dignity was under the influence of Marx/and Marxist thought - i.e. tradition that considers the possibility of human dignity as realistic only on the opposite side of alienation/exploitation. Hence a human being with dignity could exist only within conditions of common life (imposed in a revolutionary way) in which the people do not need to behave any more as "character masks that are personification of economic relations", because "all relations in which the human being used to be humiliated, oppressed, abandoned and despised" are reversed (Marx). Following that track, Bloch's analysis (1977) introduces a convincing portray of "orthopedics of upright walk" (as a contrast to crawling to which people used to be forced by various authoritarian relations). It is well-known that revolutionary ambition has proven unrealistic; indeed, the attempts to carry it out 'against the Capital' produced new, mass and systematically embedded crawling rather than upright walk. (True, Bloch's one-sided and critically oriented utopism is responsible to some degree for some of these 'misunderstandings' but at the end of the day he also had to run away to the West.)

The modern concept of dignity, under the assumed circumstances of lack of revolution, turns on a legalistic track. It means that it focuses on a build-up of legal mechanisms of protection with no clearly defined content as well as on the trade unions' struggle to provide guarantee dignity of labour. What used to be originally seen only in the philosophical realm throughout time has become valid on the legal ground as well, as it could be seen in the following statement included in the 1977 decision of the German constitutional court (BVerfGE 45,187): "It is against human dignity to make a person a mere object in a state... because the inherent dignity of a man consists exactly in his recognition as a self-responsible personality." It refers to a lifelong 
prison sentence in the light of the Article 1 of the Constitution, which postulates inviolability of human dignity. In other words, quite in a Kantian spirit, the legal interpretation of "self-responsible personality" is a foundation of the German (and not only German) constitutional reasoning. It was derived from a specific legal/political event (i.e. adoption of the UN Universal Declaration of Human Rights, which postulates that people are born "free and equal in dignity and rights" (Article 1). Thus dignity has been lifted up to the level of human rights, simultaneously getting rid of its (constantly emphasised) conflictual and exclusivist meaning. On one hand, it resulted into inflatable use of the term, so for instance (quite in a traditionalist manner) many speak of a loss of dignity of a State (that has been often bombarded by its neighbour) (Mizroch 2008). On the other hand, there is a reference to a 200 -years long call on dignity of individuals, protected by international law. At the same time, quite often, the original dichotomy of the relationship between status-related and inherent dignity is often repeated (Valentini 2017).

No matter how hard the legal theory (and jurisprudence) has tried to bring precision into the basically philosophical notion of dignity, it is usually been additionally obsfucate in other (legal, moral, political etc.) problems. For instance, somewhat wider interpretation of the aforementioned decision of the German constitutional court leads to some consequences (that the court did not have in mind) on the morally unacceptable nature of any nationalism, which by default makes any individual an "object" of its "historical project" for the sake of preservation of its creation/sustainability of its nation state. National dignity (that is "individualized" in a nationalistic way) is interpreted on the level of "nature;" exclusivity, i.e. in collision with others. It approximately mirrors the chronological beginning of the process of legalization of the philosophical concepts, i.e. the understanding that William Blackstone (2003) introduces in his deliberation of royal dignity. The king's dignity has certain meaning only "vis-à-vis others and not in relation to things that one enjoys together with his subjects". Thus dignity is a privilege: subjective one is it refers to self-understanding, and objective one if supported by institutions of a real order.

Thus respect for the others is equalized with the respect for their dignity, which leads towards respect for an individual's capacity for autonomy (something that is essential for the utilitarianism). In the words of Jon Elster (1983, p. 109): „Why would an individual seek satisfaction through the criterion of justice or societal choice if the individual aspirations could be modelled through the process that precedes choice?". In other words, if the starting point is the guaranteed individual dignity through one's autonomy, then society has been established from the bottom, as a consequence of the decisions, activities and values of individuals. Consequently, any radical ground for the dissatisfaction because of oppressed dignity (of a few and/ or many) would shed doubt over the society itself as well as on its community. Even more, it will aspire to get rid of (i.e. blow up) any trans-individual constructs. This "blow up" project starts with the removal of the "usual ways of expression" - it is what is reprimanded to those who are radically dissatisfied, i.e. the critics claim that they articulate their anger in a "way that is not acceptable to the majority". But when it is a matter of deep rage (which is usually a type of reaction provoked by denial of human dignity) it seems that the only things available is either 
the Hessel-Marcuse model of abstract 'heavy (verbal) artillery' - or manifest breach of the rules of allowed/decent speech (see Dworkin 1977, p. 201).

Moving from controversialist to the factual questioning the system - in principle, just one step is needed. But in practice, however, it is a century long process, which usually stops exactly on the questioning/challenging the system; the entire cycle may recur again - but the system remains. The imprecision of the dynamic element of "deep dissatisfaction/rage" (mentioned in the introduction of this article) as well as the consequential disorientation of the rebellion is evidently present in all these attempts.

Simultaneously, the societal (trade union's) work on dignity as a desired category of everyday life goes through a similar trajectory. Getting distanced from radical aspirations for system change, trade union action (primarily in Western Europe and USA) is mostly focused on (widely comprehended) dignity of labour. It usually has two-fold meaning:

a) as a marker for labour that enables dignified life of the workers (i.e. elimination of poverty, lack of education or cultural marginalization);

b) as a marker of labour that physically and hierarchically does not ask mistreatment and humiliation of workers.

Nevertheless, again dignity is insufficiently defined despite the fact that it's clear that it is a matter of status-related dignity. In their everyday activities thus trade unions call for quantification of their demands both for the sake of bargaining with the employers and because of legitimizing their (at least, partial) success before its membership. Yet, attractiveness of the (vague) notion of dignity remains unsurpassable, both as an intial motivation for joining the trade unions and for keeping the tensions towards the employers and the goals, that are of vital importance for trade unions' continuous functioning.

\section{Conclusion}

It seems that dignity still provokes misunderstandings on all sides, epochs and ideologies. But its original radicalism makes it inexhaustible source of a vast scale of controversial aspirations. It may seduce the masses up to the very limits of existence and even beyond; the legendary Yugoslav slogan of 27 March 1941 "Better grave than a slave" exemplarily introduces the concept of dignity in death as something more valuable than the undignified life, far before the modern ethical debates over euthanasia as a legitimate response to undignified death (interestingly, the famous Swiss clinic that provides such services bears the name "Dignitas"). Dignity that by its very demand and essence goes beyond life itself is emancipated from its existential assumption - it bypasses or goes beyond individual lives that are (in adequate phraseology) "laid/given" for the sake of dignity of others. Real life is possible only in a heroic modus, and anyone who agrees to a little more of a slavish life instead of heroic death must be seen as a coward (referring to the famous Aristotle's claim about the nature of slaves).

No matter how difficult it is to determine the meaning of dignity, its negation is unquestioned trigger of dissatisfaction and rage with various scopes and types; it is remarkable in- 


\section{Securitity}

tellectual (but also emotional) ground of any politically disorganized (but powerful) negation. Whenever that denial is being cultivated - politically or artistically - as idealized despair, it is disastrous for any social status or political order. In an attempt to gain dignity in society, the actions take a level of majestic quality, and denial of all existing. In case such a political position tries to realize itself practically, it inevitably leads to the issue of pragmatic action in which the key criterion is quantity, which de facto ruins the original grandeur of the cause/goal.

Therefore, the still unanswered and probably a question that is impossible to fully answer to is the one about possibility of embedment of relay baton, which would enable transfer from the value denial (quality) into the sphere of realization (quantity). In other words, is it possible to conceive politics of quality that would make dissatisfaction, and even despair because of loss of dignity a basis for public act that does not threaten the very idea of dignity.

\section{References}

1. Blackstone William (2003), Commentaries on the Laws of England, The Lawbook Exchange.

2. Bloch Ernst (1977), Prirodno parvo i ljudsko dostojanstvo, Beograd: Komunist.

3. Dworkin Ronald (1977), Taking Rights Seriously, Cambridge Mass.: HUP.

4. Elster Jon (1983), Sour Grapes, Cambridge: CUP.

5. Hessel Stephane (2011), Time for Outrage! Indignez-vous!, Twelve.

6. Hobbes C.B., Leviathan, (ed. C. B. Macpherson) (1982),Penguin Classics.

7. Kant Immanuel (2016), Grundlegung zur Metaphysik der Sitten, Hamburg: Felix Meiner Verlag.

8. "'Ljudi podcjenjuju snagu ljutite djece': Greta Thunberg upozorila da su mladi ljuti i frustrirani zbog klimatskih promjena", Hina, 3. 12. 2019, available at https://net.hr/danas/ svijet/ljudi-podcjenjuju-snagu-ljutite-djece-greta-thunberg-upozorila-da-su-mladi-ljuti-i-frustrirani-zbog-klimatskih-promjena/\# laccessed on 4 March 2020).

9. Marcuse Herbert (1978), Kraj utopije. Esej o oslobođenju, Zagreb: Stvarnost.

10. Marx Karl, Das Kapital I, MEW, Bd. 23, S. 64, available at http://www.mlwerke.de/me/ me23/ (accessed on 4 March 2020).

11. Marx Karl, Zur Kritik der Hegelschen Rechtsphilosophie. Einleitung, MEW, Bd. 1, S. 385.

12. Mizroch A. (2008), "Sderot Mayor: State of Israel Has Lost Its Dignity", The Jerusalem Post, 26 February.

13. Pico della Mirandola Giovanni (1994), Oratio De hominis dignitate, Studio Tessi.

14. "Predsjednica uputila oproštajnu poruku: 0 mom radu progovorit će povijest", N1 Hvatska, 15 February 2020, available at http://hr.nlinfo.com/Vijesti/a483553/Predsjednica-uputila-oprostajnu-poruku-0-mom-radu-progovorit-ce-povijest.html laccessed on 4 March 2020)

15. Schiller Friedrich (1969), Über Anmut und Würde, online version available at https:// archive.org/details/SchillerAnmutUndWurde/page/n1/mode/2up (accessed on 4 March 2020)

16. Schiller Friedrich (1980), "Musen-Almanach für das Jahr 1797", J.G. Cottaischen Buchhandlung, 


\section{Security}

17. Tübingen, "Sämtliche Werke“, Band 1, München, 1980.

18. Twain Mark (1994), Adventures of Huckleberry Finn, Dover Publications.

19. Valentini Laura (2017), "Dignity and Human Rights: A Reconceptualisation“, Oxford Journal of Legal Studies, 37(4). 